Mol2Net-04, 2018, BIOCHEMPHYS-01 (pages 1- x, type of paper, doi: $x x x-x x x x$

http://sciforum.net/conference/mol2net-4

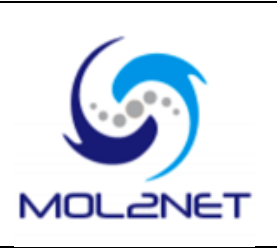

\title{
PGPB Seed biopriming Induces wheat salinity tolerance
}

Adel HADJ BRAHIM ${ }^{1}$, Mouna JLIDI $^{1}$,Lobna DAOUD ${ }^{1,2}$, Manel BEN ALI ${ }^{1,2},{ }^{3}$ smahen Akremi ${ }^{1}$, Houda HMANI ${ }^{1}$, Samir BEJAR ${ }^{1}$, Nacer Aliye Feto ${ }^{3}$ and Mamdouh BEN ALI ${ }^{1,2}$

1 Laboratory of Microbial Biotechnology and Engineering Enzymes (LBMIE), Center of Biotechnology of Sfax (CBS), University of Sfax, Road of Sidi Mansour km 6, PO Box 1177 Sfax 3018, Tunisia; E-Mails: adelhadjibrahim@gmail.com (Adel HAJ BRAHIM); asmahen.akremi@gmail.com (Asmahen Akremi); houda_enis@yahoo.fr (Houda HMANI); samir.bejar@cbs.rnrt.tn (Samir BEJAR)

2 Astrum Biotech, Business incubator, Center of Biotechnology of Sfax (CBS), University of Sfax, Road of Sidi Mansour km 6, PO Box 1177 Sfax 3018, Tunisia; E-Mails: lobna.daoudm@gmail.com (Lobna DAOUD); manel.benali@gmail.com (Manel BEN ALI); mamdouh.benali@cbs.rnrt.tn (Mamdouh BEN ALI)

3 OMICS Research Group \& Facility: Department of Biotechnology, Faculty of Applied \& Computer Sciences, Vanderbijlpark Campus, Private Bag, X021 - Vanderbijlpark - 1911 - Andries Potgieter Blvd - South Africa; E-Mail: naserf@vut.ac.za

* Author to whom correspondence should be addressed; E-Mail: hadjibrahimadel@yahoo.fr

Received: / Accepted: / Published:

\begin{abstract}
.
The present study was conducted to isolate and identify PGPB associated with two halophyte plants from coastal saline site. These strains were tested for improved crop productivity under salinity conditions. Four strains namely MA9, MA14, MA17 and MA19 were selected

The PGPB-inoculated plants were relatively healthy and hydrated, whereas the uninoculated plant leaves were desiccated in the presence of $125 \mathrm{mM} \mathrm{NaCl}$. The percentage of water content (PWC) in the plant was also significantly higher in inoculated plants compared to uninoculated ones. Under greenhouse experiments, our data revealed that experiments using seed biopriming on non-sterile soil supplemented with $\mathrm{NaCl}$ permitted to identify the most efficient isolates which offered the best vegetable criteria by significantly increasing root and shoot length, root and shoot dry weights, area of the root system and thousand seed mass in plant growth trials. The benefic effect of seed biopriming was more pronounced in soil samples added with $\mathrm{NaCl}$ than that of untreated soil.

Seed biopriming by efficient PGPB strains induced salinity tolerance of wheat and therefore enhanced their productivity under salinity.
\end{abstract}

Keywords: biopriming, halotolerant PGPB, N2 fixation, durum wheat, salinity. 
Mol2Net-04, 2018, BIOCHEMPHYS-01 (pages 1- x, type of paper, doi: $x x x-x x x x$ http://sciforum.net/conference/mol2net-4

\section{Introduction}

Salinity is one of the most severe abiotic stresses limiting crop yield. Salt-affected area in Tunisia is fast escalating due to intrusion of saline water on arable land and use of chemical fertilizers and pesticides. Thus, a great effort is required to preserve crop production under limiting factors.

Novel agricultural technologies are required to improve food production in saline and dry soils (1).Several studies have documented beneficial effects of certain rhizobial strains in improving growth of legumes as well as non-legumes. Second, inoculation of rhizobium in consortium with free-living rhizospheric bacteria has also given excellent results in improving crop growth and productivity $(2 ; 3 ; 4)$. These PGPBs can be used effectively to meet the nutrient-deficient conditions and their use can be favorable to reduce the uses of chemical fertilizers and support of environment friendly crop productivity $(5 ; 6)$. The beneficial and plant growth enhancing effects of PGPB are well reported and explained. PGPB inoculation has increased different crop yields in normal and stress conditions. From recents studies, PGPB inoculation increased the stress resistance and production of the crops, including tomato (7), wheat (8), soybean (9), groundnut (10), maize
(11) and chickpea (12). The increase in yields and other yield parameters can be different in different crops and environments and normally range from $25 \%$ to $65 \%$.

\section{Results and Discussion}

The screening results of PGP traits are summarized in Tables 1.All isolates were negative for $\mathrm{HCN}$ whereas positive for lytic enzymes production such as beta-glucanase, protease, chitinase and amylase, EPS secretion, ACC deaminase production, and diazotrophic potentiel (azote fixation).The antifungal activity of all strains was checked against Fusarium solani, $F$. oxysporum, $F$. graminarum andRhizoctonia solani using PDA medium (table1). The antifungal activity of the tested strains varied according to PGPB and phytopathogenic fungal strain whose MA17 as the most effective against all fungal strains. It should be noted that only with MA17, this activity was efficient against Fusarium oxysporum.Moreover, no antifungal activity was noticed with MA14. However, with MA9 and MA19, the antifungal activity was highly effective against Rhizoctonia solani, but less effective against Fusarium solani.

Table 1: Plant growth-promoting and other properties of selected isolates from coastal saline soil in Tunisia

\begin{tabular}{|c|c|c|c|c|c|c|c|c|c|c|}
\hline \multirow[b]{2}{*}{$\begin{array}{l}\text { Isolate } \\
\text { code }\end{array}$} & \multicolumn{3}{|c|}{ Hydrolytic enzyme properties } & \multicolumn{3}{|c|}{ PGP properties } & \multicolumn{4}{|c|}{ Mycelial growth inhibition } \\
\hline & $\begin{array}{c}\text { Beta } \\
\text { Glucanase }\end{array}$ & Protease & Chitinase & $\begin{array}{c}\text { Diazotrophic } \\
\text { potentiel }\end{array}$ & $\begin{array}{c}\text { ACC } \\
\text { deaminase* }\end{array}$ & EPS & $\begin{array}{c}\text { Rhizoctonia } \\
\text { solani }\end{array}$ & $\begin{array}{l}\text { Fusarium } \\
\text { solani }\end{array}$ & $\begin{array}{l}\text { Fusarium } \\
\text { oxysporum }\end{array}$ & $\begin{array}{c}\text { Fusarium } \\
\text { graminarum }\end{array}$ \\
\hline MA9 & ++ & +++ & + & + & +++ & ++++ & +++ & + & - & + \\
\hline MA14 & +++ & ++++ & ++ & ++ & ++ & + & - & - & - & - \\
\hline MA17 & +++ & ++++ & +++ & +++ & + & ++++ & +++ & +++ & ++ & +++ \\
\hline MA19 & +++ & +++ & ++++ & ++ & +++ & + & +++ & + & - & +++ \\
\hline
\end{tabular}


Mol2Net-04, 2018, BIOCHEMPHYS-01 (pages 1- x, type of paper, doi: $x x x-x x x x$ http://sciforum.net/conference/mol2net-4
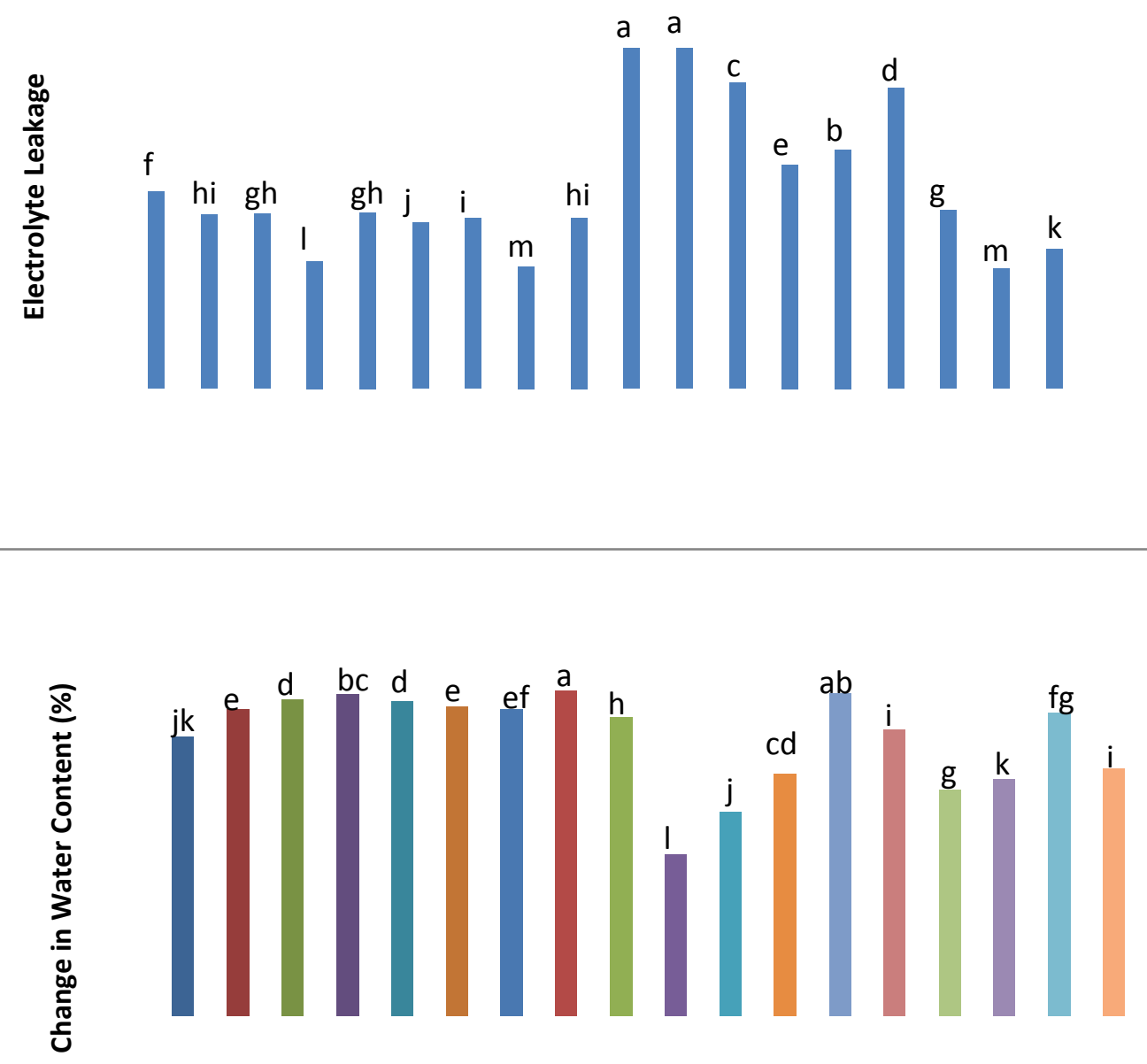

Figure 1: Effect of biopriming PGPB on the electrolyte leakage (A) and the variation of water content (\%) (B) of durum wheat plants under two salinity regimes T1and T2 (25 and $120 \mathrm{mM})$. Different letters above the histograms indicate significant difference at P B 0.05 . Two Control $\mathrm{T} 1=$ no bacterial treatment under normal conditions $(25 \mathrm{mM}) ; \mathrm{T} 2=$ no bacterial treatment under salinized hydroponic culture $(120 \mathrm{mM})$; Biop $=$ biopriming seed; BiopInoc $=$ biopriming seed and Inoculation with PGPB strains; $1=$ MA9; $2=$ MA14; 3 $=$ MA17: $4=$ MA19

Different physiological parameters such as electrolyte leakage, and water content were analyzed in the PGPB bioprimed/inoculated plants under 25 and $125 \mathrm{mM} \mathrm{NaCl}$.The PGPBinoculated plants were quite healthy and hydrated, whereas the uninoculated plant leaves were desiccated in the presence of $125 \mathrm{mM}$ $\mathrm{NaCl}$. In the control plants, the percentage increase in the water content in plants was significantly low, whereas bioprimed plants showed a higher percentage of water content (Fig.1).PGPB helps the plant by removing the physiological drought under salt stress and increasing water content in the cell. Under stress and in the absence of any bacterial treatment, the plant was found to suffer from a turgor and a reduction of the ionic potential. Nevertheless, bacterial biopriming and / or inoculation significantly improved water retention, and thus reduced leakage of electrolytes.

Inducible salt tolerance mediated by beneficial soil bacteria has been observed for several cultivated and wild plant species. The treatment of durum wheat seeds with halotolerant strains significantly improved root length under stress conditions $(125 \mathrm{mM} \mathrm{NaCl})$ as well as under 
normal growing conditions except of MA19 strain, which reduced root length by $71 \%$ in the absence of stress.However, the plant biomass was significantly increased after seed biopriming with MA17 and MA19 strains which showed a significant plant development under 25 and $120 \mathrm{mM}$, as opposed to biopriming by MA9 and MA14 which are two strains whose biopriming improves the length of the roots and has no remarkable effect on the plant biomass which is reduced by $10 \%$ with MA9 in normal culture and by $7 \%$ with MA14 under stressful conditions.Biopriming seed by these four diazotrophic strains significantly increased the dry weight of durum wheat var. "Aouija" and this induction effect is more pronounced under stress conditions than that under normal conditions.Seed biopriming with PGPB offered greater enhancement growth in comparison to control plants, whereas all experiments, under natural and saline treatment, showed a promotion in shoot and total plant length and in total dry weight of wheat plants.

\section{Materials and Methods}

Plant growth properties: for biochemical selection of PGPB, strains were examined for their nitrogen-fixation (diazotrophic) potential by the method of Quantification of $\mathrm{N}$ fixing capacity and the ARA test $(13 ; 14)$, exopolysaccharide production was performed according to Paulo et al. (2012)(15),ACC deaminase activity (16), and antimicrobial activities production (17).

Physiological response of wheat under hydroponic culture:Electrolyte leakage was measured according to Lutts et al (1996)(18). One young leaf from the first primary branch toward the distal end of the same size was collected from three plants for each treatment and washed thoroughly with deionized water to remove surface-adhered electrolytes. The samples were placed in closed vials containing $10 \mathrm{ml}$ of deionized water and incubated at $25^{\circ} \mathrm{C}$ on a rotary shaker for $24 \mathrm{~h}$, and the electrical conductivity of the solution (Lt) was determined using Seven Easy conductivity (Metler Toledo AG 8603, Switzerland). Samples were then autoclaved at $120^{\circ} \mathrm{C}$ for $20 \mathrm{~min}$ and the final electrical conductivity (L0) was obtained after cooling at $25^{\circ} \mathrm{C}$. The electrolyte leakage was defined as follows:
Electrolyte leakage $(\%)=\left(\mathrm{L}_{\mathrm{t}} / \mathrm{L}_{0}\right) * 100$. Percentage change in water content was calculated as $[(\mathrm{FW}-\mathrm{DW}) / \mathrm{FW}] * 100$ (19). Each experiment was replicated three times.

Pot trial: Seeds of wheat "Aouija" were surface sterilized with $0.1 \% \mathrm{HgCl} 2$ for 2 min and washed with sterilized water. PGPB were grown overnight in $250 \mathrm{ml} \mathrm{LB}$-liquid and culture was directly harvested to obtain fresh bacterial cells for preparation seed coating for biopriming seed of wheat. Natural soil was used without sterilization. Pot experiments were conducted by employing Completely Randomized Design (CRD). Trial 1: This experiment was conducted without inoculation by PGPB in small pots $(9 \mathrm{~cm}$ diameter) containing unsterilized natural soil $(150 \mathrm{mM} \mathrm{NaCl})$ as negative control. The plants grown without inoculation and sand salinization were used as positive control. Trial 2: In thisexperiment, inoculation by PGPB in $(9 \mathrm{~cm}$ diameter) small pots containing unsterilized sand $(1 \mathrm{Kg} / \mathrm{pot})$ salinized by $150 \mathrm{mM}$ and without seed bacterization. The pots containing natural soil without seed bacterization were used as positive control.Trial 3: The experiment was conducted with inoculation by PGPB in $(9 \mathrm{~cm}$ diameter) small pots containing unsterilized sand $(1 \mathrm{Kg} / \mathrm{pot})$ salinized by $150 \mathrm{mM}$ and with seed bacterization. The pots containing natural soil with seed bacterization were used as positive control.

\section{Statistical Analysis}

The data generated during quantitative evaluation of biochemical characteristics and seed germination or plant growth promotion values were analyzed by the Duncans Multiplicity Test Range (DMRT) using the SPSS software (ver. 10.1, SPSS Inc., www.spss.com). The significance level for all analysis was $\mathrm{P}=0.05$.

\section{Conclusions}

Our data revealed efficient isolates that offered the best vegetable criteria by significantly increasing root and shoot length, total dry weights, area of the root system and 100 seed mass in plant growth trials when applied on wheat seeds germinated under salt stress conditions In fact, the benefic effect of seed bacterization was more pronounced in soil samples added with $\mathrm{NaCl}$ than that of untreated soil. These characteristics are important growth 
Mol2Net-04, 2018, BIOCHEMPHYS-01 (pages 1- x, type of paper, doi: $x x x-x x x x$

http://sciforum.net/conference/mol2net-4

promoting traits for plants growing in the region under continuous threat of soil erosion and soil degradation.The effectiveness of seed biopriming with PGPBbefore germination suggests the possible use of these strains to reduce the chemical fertilizers concentrations as a low cost and effective management strategy.

\section{References}

1. Wehrheim P, Martius C (2008) Farmers, cotton, water, and models Introduction and overview In: Wehrheim P, Schoeller-Schletter A, Martius C (eds) Continuity and change: Land and water use reforms in rural Uzbekistan Socioeconomic and legal analyses for the region Khorezm Halle/Saale, IAMO, pp 1-16.

2. Kishore GK, Pande S, Podile AR. Phylloplane bacteria increaseseedlingemergence, growth and yield of field-growngroundnut (ArachishypogaeaL.). LettApplMicrobiol2005;40: 260-8.

3. Tilak KVBR, Ranganayaki N, Manoharachari C. Synergistic effect of plant growth promoting rhizobacteria and Rhizobiumonnodulation and nitrogenfixationbypigeonpea (Cajanuscajan). Eur $J$ Soil Sci2006;57:67-71.

4. Wani PA, Khan MS, Zaidi A. Effect of metal tolerant plant growth promoting Bradyrhizobium sp. (vigna) on growth, symbiosis, seed yield and metal uptake by green gram plants. Chemosphere 2007; 70:36-45.

5. Herrera MA, Salamanka CP, Barea JM. Inoculation of woodylegumes with selectedarbuscularmycorrhizalfungi and rhizobiatorecoverdesertifiedMediterraneanecosystems. ApplEnvironMicrob1993;59:129-33.

6. Requena $\mathrm{BN}$, Jimenez I, Toro $\mathrm{M}$ et al. Interaction between plant growth promoting rhizobacteria (PGPR) arbuscular fungi and Rhizobiumspp. in the rhizosphere of Anthylliscytiisoides, a modellegume for regeneration in Mediterranean semi-arid ecosystem. New Phytol1997;136:66777.

7. Almaghrabi OA, Massoud SI, Abdelmoneim TS. Influence of inoculation with plant growth promoting rhizobacteria (PGPR) on tomato plant growth and nematode reproduction under greenhouse conditions. Saudi J BiolSci2013;20:57-61.

8. Jaderlund L, Arthurson V, Granhall U et al. Specificinteractionsbetweenarbuscularmycorrhizal fungi and plantgrowthpromoting bacteria: as revealed by different combinations. FEMS MicrobiolLett2008;287:174-80.

9. Masciarelli O, Llanes A, Luna V. A new PGPR co-inoculated with Bradyrhizobium japonicumenhancessoybeannodulation. MicrobiolRes2014;169:609-15.

10. Paulucci NS, Gallarato LA, Reguera YB (2015) ArachishypogaeaPGPR isolated from Argentinesoilmodifiesitslipidscomponentsin response totemperature and salinity. Microbiol Res 2015;173:1-9.

11. Rojas-Tapias D, Moreno-Galv'an A, Pardo-D'iaz S (2012) Effect of inoculation with plant growth-promoting bacteria (PGPB) onamelioration of saline stress in maize (Zea mays). Appl SoilEcol2012;61:264-72.

12. Patel HA, Patel RK, Khristi SM et al. Isolation and characterization of bacterial endophytes from Lycopersiconesculentumplant and their plant growth promoting characteristics. NepalJ Biotechnol2012;2:37-52.

13. Kizilkaya, R 2009 Nitrogenfixationcapacity of Azotobacter sppstrainsisolated from soils in differentecosystems and relationship between them and themicrobiological properties of soils $\mathrm{J}$ EnvironBiol, 30: 73-82.

14. Doebereiner J (1995) Isolation and identification of aerobic nitrogen-fixing bacteria from soil and plants In: Alef K, Nannipieri P (eds) Methods in appliedsoilmicrobiology and biochemistryAcademic, London, pp 134-141.

15. Paulo EM, Vasconcelos MP, Oliveira IS, Affe HMJ, NascimentoR, Melo IS, et al. An alternative method for screening lactic acid bacteria for the production of exopolysaccharides with rapid confirmation. CiêncTecnolAliment, 2012, 
Mol2Net-04, 2018, BIOCHEMPHYS-01 (pages 1- x, type of paper, doi: $x x x$-xxxx

http://sciforum.net/conference/mol2net-4

16. Penrose DM, Glick BR (2003) Methodsforisolating and characterizing ACC deaminasecontainingplant growth promoting rhizobacteria PhysiolPlant 118:10-15.

17. Desai, S, Reddy, M S and Kloepper, J W (2002) Comprehensivetesting of biocontrol agents In: Biological Control of CropDiseases, pp 387-420 Ed S SGnanamanickam Marcel Dekker, Inc, New York· Basel, USA.

18. Lutts S, Kinet JM, Bouharmont J (1996) NaCl-inducedsenescence in leaves of rice (Oryza sativa L.) cultivarsdiffering in salinityresistance. Ann Bot 78:389-398.

19. Zhang HX, Blumwald E (2001) Transgenic salt-tolerant tomato plants accumulate salt in foliage but not in fruit. Nat Biotechnol 19:765-768. 